\title{
O LUGAR DO IMAGINÁRIO NA FORMAÇÃO DE PROFESSORES E A CRIAÇÃO DE AVATARES NA UNIVERSIDADE
}

\author{
Valeska Maria Fortes de Oliveira ${ }^{1}$ \\ Ana Iara Silva de Deus ${ }^{2}$ \\ Samara $\mathrm{Facco}^{3}$
}

\begin{abstract}
Resumo: Este artigo discorre sobre um projeto de produção de avatares, com acadêmicos de graduação, professores e acadêmicos do programa de Pós-Graduação em Educação-UFSM. O desenvolvimento desse trabalho objetivou mobilizar os envolvidos para projetarem-se como super-heróis universitários, potencializando seu poder de "criação", através do imaginário social, para que possíveis mudanças possam ser repensadas no âmbito educacional. Dessa forma, a invenção do super-herói universitário instigou a elaboração de um manifesto grafopoético, um texto crítico para a área da educação, em que os participantes deveriam formular um apelido-verbete, suas qualidades visuais, sua predestinação, seu oponente, seu ponto forte e fraco, seu instrumento de poder, por meio de metáforas que imaginavam um campo alegórico para a Universidade. Assim, a partir desta experiência, foi possível pensar sobre as questões postas na formação de professores pelo viés do imaginário social, especialmente sobre as significações imaginárias dos acadêmicos e professores acerca da universidade e de seu papel na sociedade.
\end{abstract}

Palavras Chaves: Educação. Imaginário Social. Formação de Professores.

\section{EL LUGAR DEL IMAGINARIO EN LA FORMACIÓN DE PROFESORES Y LA CREACIÓN DE AVATARES EN LA UNIVERSIDAD}

Resumen: Este artículo versa sobre un proyecto de producción de avatares, con académicos de graduación, profesores y académicos del programa de Postgrado en Educación-UFSM. Se utiliza para esta escritura autores, como: Castoriadis (1982), Peres \& Kurek (1990), entre otros. El desarrollo de este trabajo tuvo como objetivo movilizar a los involucrados para proyectarse como superhéroes universitarios, potenciando su poder de "creación", a través del imaginario social para que posibles cambios puedan ser repensados en el ámbito educativo. De esta forma, la invención del superhéroe universitario, instigó la elaboración de un manifiesto grafo poético, un texto crítico para el área de la educación, donde los participantes debían formular un sobrenombre-verbete, sus cualidades visuales, su predestinación, su oponente, punto fuerte y débil, su instrumento de poder, por medio de metáforas que imaginaban un campo alegórico para la Universidad. Así, a partir de esta experiencia fue posible pensar sobre las cuestiones planteadas en la formación de profesores por el sesgo del imaginario social, especialmente sobre las significaciones imaginarias de los académicos y profesores acerca de la universidad y de su papel en la sociedad. Por lo tanto, con el desarrollo de este proyecto fue posible analizar las significaciones imaginarias como un magma, de donde se puede extraer y / o construir innumerables formas, maneras de ser y hacer de cada sociedad o grupo social. Esta propuesta se caracterizó como creativa por trabajar con el imaginario social y utilizar la proyección de los superhéroes como un manifiesto grafico-poético, algo de extrema importancia en ese territorio donde la comodidad habita diariamente el escenario actual.

Palabras claves: Educación. Imaginario Social. Formación de profesores.

\footnotetext{
${ }^{1}$ Professora Doutora e responsável pelo departamento de Fundamentos da Educação na Universidade Federal de Santa Maria. Coordenadora do Grupo de Estudos e Pesquisa em Educação e Imaginário Social-GEPEIS-UFSM. Contato: vfortesdeoliveira@gmail.com

${ }^{2}$ Graduada em Pedagogia, pós-graduada em Educação Infantil, Arteterapeuta, Mestre em Educação. Atualmente, é doutoranda do PPGE da Universidade Federal de Santa Maria. Integra o grupo de Pesquisa em Educação e Imaginário Social-GEPEIS da UFSM. É Pesquisadora Caps da UFSM. Contato: anaiaradeus@hotmail.com

${ }^{3}$ Graduanda do Curso de Pedagogia da Universidade Federal de Santa Maria, aluna bolsista do Grupo de Estudos e Pesquisa em Educação e Imaginário Social-GEPEIS-UFSM. Contato: faccosamara8@gmail
} 


\section{O IMAGINÁRIO SOCIAL E A FORMAÇÃO DE PROFESSORES}

O Grupo de Estudos e Pesquisas em Educação e Imaginário Social - GEPEIS, nos últimos vinte e cinco anos, trabalha com formação de professores sob a ótica do Imaginário Social na Universidade Federal de Santa Maria. E, desde então, já transitou por temas como racismo, gênero, transgênero, grupos, dispositivo, tempo, docência universitária, todos estes vistos a partir das lentes do imaginário.

Desse modo, o GEPEIS, ao longo desses anos, tem se dedicado aos estudos do campo simbólico da educação, entendendo que o que caracteriza algo é a capacidade de criar. E, assim, instituímos formas de viver nas instituições, (res) significando-as à medida que não fazem mais sentido e vão sendo pensadas outras formas (eidos). Assim, mesmo nos processos de formação de professores, aproximamo-nos dos sentidos e significados construídos acerca da docência, do ser professor e da sua representação na sociedade brasileira. Esse é sempre o passo inicial. Conhecer as significações construídas pelos professores e o campo biográfico tem sido potente para, metodologicamente, produzirmos narrativas e aproximações com os imaginários docentes.

Os movimentos das narrativas aos imaginários acompanham o trajeto formativo e investigativo da universidade e das escolas das diferentes redes, com as quais possuímos parcerias, tentando produzir desaprendizagens/aprendizagens, pois é nessa espiral que pensamos em dispositivos, passíveis de acionar a formação.

\section{O IMAGINÁRIO NO CONTEXTO DA FORMAÇÃO}

O campo do imaginário social foi escolhido pelo Grupo de Estudos e Pesquisas em Educação e Imaginário Social (GEPEIS) nos últimos vinte e cinco anos para a leitura e diálogo com as questões da educação, pois entende-se que o olhar atento e com um cuidado ético sobre o simbólico da educação tem permitido contribuir não com respostas prontas ou receitas para os desafios vividos pelos professores nos seus contextos de trabalho, mas, principalmente, vem provocando a criação de dispositivos capazes de implicar-nos e implicarmos outros docentes com seus trajetos.

Adentrar no simbólico é produzir aproximação com sentidos e significados produzidos social e individualmente. Mesmo sabendo que não conhecemos o imaginário, aproximamo-nos do que se mostra, do que nos mostram, do que elegem mostrar. Nosso grupo tem se utilizado da dimensão (auto) biográfica da pesquisa para uma aproximação dos imaginários através das narrativas do vivido. 
Que contribuições podemos trazer com estes estudos nas questões educacionais, por exemplo, no debate da diversidade, das questões étnicas, das questões de gênero e transgênero? Que outras cores podemos trazer ou produzir com os estudos do imaginário, juntos com outros atores sociais no cotidiano da sociedade e da educação? Que movimentos podemos provocar conosco e com as pessoas que temos convidado a participar dos nossos projetos de ensino, pesquisa e extensão? Que conceitos movimentam no campo do imaginário com desdobramentos na formação inicial e continuada de professores e na produção de conhecimento do campo? Essas e outras questões constituem o protocolo de estudos e pesquisas direcionados à formação de professores.

O envolvimento com este campo teórico permite afirmar que estamos num território cimentado por crenças, mitos, ritos que não são modificados rapidamente, muitas vezes, nem mesmo de uma geração para outra. Ainda temos visto que as criações na nossa sociedade são naturalizadas, inviabilizando, muitas vezes, as transformações ou a imaginação que coloca outras formas no lugar das que não fazem mais sentido nem individual e nem coletivamente.

\section{AS INSTITUIÇÕES VISTAS COMO UMA CRIAÇÃO IMAGINÁRIA SOCIAL}

A escola e a universidade são invenções da sociedade. Como tais, quando criadas, foram pensadas a partir da lógica conjuntista-identitária, pelo seu caráter funcional e, ainda, pela sua significação imaginária, sua dimensão simbólica. Nesses dois movimentos, são depositadas expectativas que acompanham o tempo social e histórico a partir das suas demandas.

Apreender os sentidos que têm as instituições para determinados grupos significa decifrar uma pluralidade de imagens e de linguagens que têm passado despercebidas nas pesquisas em educação e nos projetos com as escolas e os professores.

Desconhecemos e não nos dedicamos a entender o universo imaginário, como rede de sentidos, em que, segundo Ferreira e Eizirik (1994, p. 7),

... aparecem as crenças e fantasias, desejos e necessidades, sonhos e interesses, raciocínios e intuições: uma gama de elementos fundantes do processo de simbolização. (...) ele institui, histórica e culturalmente, o conjunto de interpretações, das experiências individuais, vividas e construídas coletivamente.

Dedicarmos a escuta e a observação à dimensão simbólica da escola e da universidade é considerar os grupos sociais que nela interagem. Estar atento às 
manifestações dos sujeitos na sua interação cotidiana é fundamental para compreender a complexidade e heterogeneidade das relações intersubjetivas.

Entendemos que o discurso e a análise da educação centrada em apenas uma dimensão do homem, por exemplo, no homo faber, mostram a sua limitação. A ordem do econômico também não consegue explicar todas as situações evidenciadas na realidade social e mesmo cultural. A caracterização do homem como racional não dá conta da complexidade constitutiva desse ser.

Entretanto, de acordo com Cassirer (1994, p. 50),

o homem já não pode fugir à própria consecução. Não vive num universo puramente físico, mas num universo simbólico. A linguagem, o mito, a arte e a religião são partes deste universo. São os vários fios que tecem a rede simbólica, a teia emaranhada da experiência humana.

Já não é dada ao homem a condição de enfrentar a realidade de forma direta, desprestigiando as instâncias intermediárias. Passou a envolver-se em formas linguísticas, em imagens artísticas, em símbolos, em mitos, em ritos, e constituem os seus interditos.

Esse entendimento acaba apontando para outras dimensões que se apresentam como emergentes na análise educacional, tais como as que salienta Scholl (apud Teves, 1992, p. 105).

Quando a escola tenta recuperar a sua dimensão de produzir bens de sentidos, os estudos teóricos e práticos sobre o imaginário social poderão abrir um outro campo para a análise dos problemas educacionais. Estes, até então, vinham sendo tratados, quase que exclusivamente por seu lado racional e tecnicista, já que as crenças, os mitos, as expectativas e os desejos da sociedade, como um todo, eram praticamente desprezados.

Apresentando o imaginário na relação pedagógica, Postic (1993, p. 13) afirma que

Imaginar é evocar seres, coloca-los em determinada situação, fazê-los viver como se quer. É criar um mundo a seu bel-prazer, libertando-se. Tudo é possível. Tudo acontece. Na vida artística, imaginar é um ato criador. Na vida cotidiana, imaginar é uma atividade paralela à ação que exercemos ligada à realidade. A imaginação é um processo. $\mathrm{O}$ imaginário é seu produto.

Segundo o autor mencionado anteriormente, a imaginação é uma atividade de reconstrução do real, a partir dos significados que atribuímos aos acontecimentos ou das 
repercussões que estes causam em nós. O imaginário estaria povoado de representações simbólicas do real. Etimologicamente, ressalta que a imaginação é solidária de imago, de representação, de imitação e de reprodução. À imaginação caberia imitar modelos exemplares - as imagens; ela as reproduziria, reatualizaria-as.

Assim, buscamos no mundo das imagens e dos símbolos um significado situado no plano racional. Essas relações que estabelecemos são o centro da nossa vida imaginária. A escola e a universidade são instituições criadas historicamente com uma função social e a partir de uma dimensão simbólica. Enquanto espaço público destinado a todos, vai simbolizar uma possibilidade de acesso ao ensino - que é uma porta para "uma vida melhor" e com melhores oportunidades. Simbolicamente, também será uma forma que fará a diferença daqueles que "conseguiram ascender socialmente".

Modernamente, a escola é o espaço dedicado à educação formal, ao acesso ao código escrito e falado da sociedade, à formação do aluno crítico para o exercício da sua cidadania e à disciplinarização dos corpos. Significa ainda o acesso à uma futura profissão, à independência, à possibilidade de "subir na vida", segundo o mito moderno do progresso.

A ascensão social vinculada a uma "boa profissão" faz parte desse imaginário, produzindo, nos estudantes, as aspirações de conforto, bom salário, de respeito social, de progresso numa estrutura hierarquizada. A universalização e a quebra de uma estrutura social rígida permitem uma relativa mobilidade social, que vai ser empregada para reforçar esse imaginário ocidental moderno.

Investigar a escola, personalizada nos seus sujeitos, a partir de sua dimensão imaginária, constitui uma trajetória que tem início na dimensão funcional da instituição, a partir das funções que a escola deve assumir, indo além, adentrando sua dimensão simbólica.

Por meio dos estudos sobre o imaginário social, estaríamos colocando a escola no campo institucional que tenta recuperar uma das "marcas" do seu trabalho, qual seja, a de produzir bens de sentidos.

Esses estudos e pesquisas fazem parte de um campo de investigação em que a transdisciplinaridade, no sentido proposto por Morin (1991) - de ultrapassar as fronteiras de cada área de conhecimento e adentrar a outras desconhecidas -, é garantida e necessária.

Essa necessidade de ultrapassar as fronteiras da área da educação e adentrar outras áreas do conhecimento começa por estabelecer um diálogo necessário para que se possa 
compreender os processos de significação e, também, estabelecer estratégias que viabilizem uma escola, a partir do sentido das práticas para aqueles que a frequentam.

Como apontam Ferreira e Eizirik (1994, p. 10),

É possível, pois, trabalhar as resistências, incentivar as forças criadoras do grupo quando se conhecem os mitos, os símbolos que lhe servem de suporte. Para cumprir seu papel, a escola não pode ficar presa a velhas definições. Na busca de representar um projeto para o futuro, melhor que o anterior, precisa, sobretudo, rever seu próprio conceito, reescrevendo o significado da palavra escola.

Reescrever o significado da palavra escola no nosso tempo, um tempo vivido em redes, em "fios", por polegares, que coloca outras exigências para o sujeito histórico e para a sociedade, é uma tarefa possível e será tanto mais significativa se realizada a partir da aproximação do que está instituído e das perspectivas traduzidas pelo instituinte.

Segundo a teoria do Imaginário Social, tudo o que se apresenta a nós, no mundo sócio-histórico, está indissociavelmente tecido no simbólico. Ele aponta que precisamos aprender a pensar de outra maneira, colocando a imaginação e o imaginário no centro. Nas palavras do próprio autor

\begin{abstract}
A história é impossível e inconcebível fora da imaginação produtiva ou criadora, do que nós chamamos o imaginário radical tal como se manifesta ao mesmo tempo e indissoluvelmente no fazer histórico, e na constituição, antes de qualquer racionalidade explícita, de um universo de significações. (CASTORIADIS, 1982, p. 176)
\end{abstract}

A partir disso, perceber as pessoas, a sociedade e suas relações a partir do imaginário é apreender o simbolismo, as significações que estas carregam, num processo que vai além das considerações formais. Mas para isso é preciso que agucemos nosso olhar às dinâmicas que nem sempre estão facilmente visíveis, pois somos movidos por correntes instituídas e instituintes de significações imaginárias.

\title{
UMA EXPERIÊNCIA FORMATIVA ENTRE DOIS GRUPOS DE PESQUISA
}

Essa experiência formativa ocorreu na Universidade Federal de Santa Maria UFSM-RS, unindo dois grupos, um deles que desenvolve pesquisas em Educação e Imaginário Social-GEPEIS, já destacado anteriormente, e outro que trabalha com um projeto de produção de avatares da Universidade Federal do Rio Grande do Sul- 
UFRGS. O desenvolvimento desse trabalho visou mobilizar os participantes para projetarem-se como super-heróis universitários. Essa proposta foi muito criativa, utilizou-se do imaginário social para instaurar possíveis mudanças na prática educacional. Dessa forma, a invenção do super-herói universitário instigou o grupo a elaborar um manifesto grafopoético, ou seja, texto crítico para a área da educação, com a finalidade de provocar movimentos instituintes.

Castoriadis define que:

Enquanto instituinte e enquanto instituída, a sociedade é intrinsicamente histórica - ou seja, auto-alteração. A sociedade instituída não se opõe à sociedade instituinte como um produto morto a uma atividade que o originou; ela representa a fixidez/estabilidade relativa e transitória das formas-figuras instituídas em e pelas quais somente o imaginário radical pode ser e se fazer ser como social histórico (1982, p. 416).

Desse modo, o autor nos esclarece sobre as mudanças que ocorrem gradualmente nas sociedades, por meio do que está instituído e por aquilo que pode vir a ser pelo movimento do instituinte, o qual decorre pelo imaginário radical, assim denominado por Castoriadis. Para o autor, as dimensões criadoras são possíveis pelo imaginário radical.

Sob essa perspectiva, podemos pensar o sujeito como um magma, incessante de imaginações criadoras, um ser inacabado, aberto para as mudanças e transitoriedades do contexto em que se encontra inserido. Além de um vir a ser, o sujeito, nessa óptica, instaura novas significações imaginárias sociais, abrindo espaços para que o instituinte se manifeste. Castoriadis diz que: "O imaginário social como instituinte constrói significações imaginárias sociais". [...] Logo cada sociedade institui-se a seu modo. (2007, p. 36). Dessa maneira, através das significações imaginárias sociais podemos instaurar novas formas de ser e estar na sociedade.

Assim, com base nas ideias desse autor, foi proposta essa experiência formativa, apostando no instituinte como possibilidade de repensar a formação continuada, por meio do imaginário social. Esse trabalho foi possível, pois o Grupo de Estudos e Pesquisas em Educação e Imaginário Social-GEPEIS trabalha com o projeto: “O lugar do imaginário na formação de professores" - o qual visa investigar as especificidades e contribuições do campo do imaginário social para as questões educacionais e a formação de professores através da constituição de um grupo interinstitucional. O projeto fundamenta-se, teoricamente, nas concepções do autor Cornelius Castoriadis, compreendendo que a 
sociedade age segundo o sentido que atribui às coisas. Nessa visão, adentrar no simbólico é produzir aproximações com significados produzidos socialmente. Dessa maneira, por meio do imaginário, no simbólico conseguimos reconstruir os elementos instituídos no campo educacional e pensar possíveis mudanças para os dados reais. Por isso, o imaginário, no contexto da formação de professores, instiga, principalmente, o pensar sobre o que está instituído na sociedade e nas questões que envolvem o trabalho docente e provoca o processo instituinte, de refletir aquilo que está posto, almejando mudanças. De acordo com Pujol, Severo e Peranzoni (2015, p. 02), "não podemos nos conformar com o instituído visto que somos seres de criação, animais simbólicos numa sociedade que espera e incentiva movimentos instituinte, ou seja, construção de novas formas de ser e estar".

Por isso, esse embasamento teórico do imaginário social de Castoriadis nos possibilita repensar as práticas instituídas na sociedade e, consequentemente, na escola. Também vislumbramos movimentos instituintes pelo viés do imaginário radical.

\section{IMAGINÁRIO SOCIAL E A PRODUÇÃO DE DICIONÁRIOS VERBETES}

O Grupo de Estudos e Pesquisas em Educação e Imaginário Social-GEPEIS trabalha com o projeto de pesquisa "O lugar do imaginário na formação de professores". Ele visa investigar as especificidades e contribuições do campo do imaginário social para as questões educacionais e a formação de professores através da constituição de um grupo interinstitucional. Sendo assim, possui parceiros com a Universidade Federal do Rio Grande do Sul-UFRGS, que coordena o dicionário raciocinado das licenciaturas, que faz parte da pesquisa de Estudos de Zona: territorialidades, biografemas e discursos em licenciaturas. A criação desse dicionário possui outros parceiros.

Essa ação de produção de super-heróis universitários acontece dentro do contexto do imaginário social de Cornelius Castoriadis, integrada com o projeto de produção de avatares e o Grupo de Estudos e Pesquisa em Educação e Imaginário Social-GEPEIS, tendo a produção dos dicionários como a ponte para esta interação, a fim de percebermos a importância de sermos super-heróis dentro da área da educação.

O grupo GEPEIS ficou muito entusiasmado durante a oficina, justamente por seu caráter imaginário, tema que se trabalha e muito se admira. As pessoas que participaram se sentiram mobilizadas e cativadas por se projetarem como super-heróis da educação, sendo assim, houve grande adesão a proposta. 
Esse fato ocorreu devido aos inúmeros desafios que integram o meio educacional e uma possível intervenção no habitual por parte do super-herói criado. Como salienta Adriano Moraes de oliveira em sua tese: "o imaginário é o que permite que nos posicionarmos frente às mais diversas situações, pois: um conjunto de imagens que nos autoriza a pensar aquilo que pensamos, assim como nos impulsiona, por meio da imaginação criadora, a novos voos, a possibilidade de futuro" (2000, p. 14).

Essa proposta se caracterizou como criativa por trabalhar com o imaginário e utilizar a projeção dos super-heróis como um manifesto grafopoético, algo de extrema importância nesse território em que o comodismo habita diariamente. Segundo Cassirer (1994, p. 104), “é o pensamento simbólico que supera a inércia natural do homem e lhe confere uma nova capacidade, a capacidade de reformular constantemente o seu universo humano".

Nesse sentido, pelo simbólico, podemos mudar as contingências das coisas que estão no entorno e escapar da inércia, principalmente no campo educacional, tão cristalizado de procedimentos ultrapassados, no entanto ditos e vistos como normais. Como assegura Castoriadis, a "realidade natural” não é apenas aquilo que resiste e não se deixa manejar: ela é também aquilo que se presta à transformação, o que se deixa alterar "condicionalmente" mediante, ao mesmo tempo, seus interstícios livres e sua regularidade (1982, p. 400).

Como se vê, o imaginário social de Cornelius Castoriadis convoca a pensar as problemáticas existentes não como ordem dada e instituída, pelo contrário, mobiliza as criações imaginárias a surgirem para serem transformadoras.

\section{O PROCESSO DE CRIAÇÃO DOS AVATARES NO AMBIENTE UNIVERSITÁRIO}

Inicialmente, houve o convite para o grupo participar do projeto de criação de avatares devido à aproximação da proposta com o imaginário social, com o qual os integrantes trabalham. Foi marcada uma data com os interessados em participar da oficina e o convite agradou aos participantes, havendo uma grande adesão, porque a atividade era diferenciada e criativa. O convite foi aberto ao público e, assim, participaram da oficina alguns representantes do Programa Institucional de Bolsas de Iniciação à Docência (Pibid), alguns alunos do curso de arquitetura, do curso de desenho industrial e muitos integrantes do GEPEIS. 
No momento da realização da oficina, foi explicado aos presentes o contexto dessa ação e a importância da criação de avatares como um meio criativo de luta pela mudança. Dessa forma, foi salientado que o virtual é utilizado nos avatares não como algo fictício, mas como forma de potência. Também foram demonstrados alguns trabalhos já realizados de super-heróis criados em outras oficinas, a fim de inspirar as futuras criações.

A proposta foi de criação grafopoético de um super-herói universitário, incluindo questões como a formulação de um apelido-verbete, suas qualidades visuais, sua predestinação, seu oponente, seu ponto forte e fraco e seu instrumento de poder. Também foi proposta a criação de um manifesto poético do super-herói, usando metáforas da personagem, do oponente, do seu poder e de sua fragilidade e imaginando um campo alegórico para a Universidade. Houve questionamento como: "O que é um herói universitário?" “O herói-universitário é um marginal?" e "É preciso ser um marginal para ser herói?"

A responsável pelo trabalho salientou que não se pode esperar que a sociedade convoque as pessoas para realizarem as mudanças necessárias, mas cada um precisa colocar-se à disposição dessa mesma sociedade. Refletiu-se, também, sobre o motivo dos super-heróis voarem ou saltitarem em vez de viver sobre o chão, e se concluiu que isso ocorre para evitar sua morte.

Essa elaboração tinha como objetivo que as criações fizessem parte de uma publicação em um livro que reuniria vários super-heróis e seus manifestos poéticos. Os resultados foram incríveis, cada um dos personagens com sua singularidade e com muitos traços de cada autor nos seus super-heróis. A criatividade dos trabalhos foi enorme, com textos críticos sobre a educação, mas com o heroico sempre presente.

\section{AS ANÁLISES E AS DISCUSSÕES DOS DADOS: SIGNIFICAÇÕES IMAGINÁRIAS COMO CAMPO CRIATIVO}

O desenvolvimento deste trabalho contou com a participação de 25 sujeitos com diferentes subjetividades e experiências profissionais, incluindo uma professora com 25 anos de magistério e estudantes em formação inicial em cursos de licenciatura. Desse modo, as experiências vivenciadas com as criações dos superheróis (nas) movimentaram as significações imaginárias através das narrativas e composição gráfico-plástica, pois puderam ser percebidas nas escritas e na construção criativa dos envolvidos no processo. 
Segundo Mastroberti, a idealização desse trabalho visa:

Integrar nas instâncias da produção e da educação, as artes visuais à produção de literária, entendendo a palavra como substância poética. Trata-se de um projeto que prioriza as modalidades gráficas híbridas, tais como quadrinhos, zines, ilustrações e outras produções em que as artes surjam sequencializadas e combinadas a textos (2016, p. 7).

O desenvolvimento desse projeto visou, como bem salientou a autora, potencializar, no cenário educacional, discursos poéticos e criativos, com o intuito de fomentar nos professores e acadêmicos uma visão consciente do cenário educacional atual, através das criações artísticas e dos textos gráfico-poéticos.

Dessa forma, os textos poéticos criados pelos participantes variaram de textos simples, cheios de espontaneidade até grafos críticos ao sistema educacional brasileiro, ressaltando a luta incessante contra os comodismos na área educacional. Assim, foi promovida a elaboração dos avatares, os quais foram personagens-metafóricos que expressaram os desejos, conflitos, planos e projeções futuras para a educação. Por isso, cada SHU (Super Herói(ína) Universitário(a)) possuía uma imensidão de características próprias que se instituíram de acordo com as experiências de cada participante, e essa foi a maior característica dos trabalhos: valorizar as escritas de cada um juntamente com suas histórias de vida em suas diferentes linguagens e não somente a quantidade de Super Heróis(nas) Universitários(as) criados.

Para Mastroberti:

Brinca de ser herói no interior da Universidade, transfigurar o espaço universitário em faz-de-conta: isso é um jogo sério. Requer comprometimento, requer disposição para sair do lugar comum e assim imaginar + ficcionalizar + virtualizar. [...] Assim, a transformação do mundo em um lugar mais bonito e mais justo pode depender do poder e da fantasia manifestos por esses heróis da educação que assinam cada verbete, e dos devaneios que eles compartilham conosco. Cada um expressa uma vontade e um poder (2016, p. 8).

A transformação do mundo em um lugar mais bonito com novas possibilidades e criações ocorrem pela capacidade simbólica e subjetiva. E essa capacidade imaginativa, criativa e estética ficou evidente em cada escrita dos participantes, nas ideais, nas mudanças e nas projeções pontuadas; outros, com vários anos de atuação profissional, expressaram, nos seus textos, as lutas que foram interrompidas pelos preconceitos e monotonias estereotipadas. 
Assim, foram escolhidos dois textos gráficopoéticos para ilustrar o processo criativo vivenciado pelos envolvidos no processo: o de uma professora com uma grande experiência na área da educação, pois está quase se aposentando do magistério superior, e uma graduanda no início da sua formação acadêmica em pedagogia. Assim, descrevem-se, primeiramente, os textos poéticos e depois as criações gráfico-plásticas das escritas.

\section{Iniciaremos com: VALESCATS a super heroín@}

Ela é soma de muitas, muitas partes, todas complexas. Cada uma é dotada de grande intensidade. Movimenta-se no território universitário na contemporaneidade inquieta, mas amorosa, provocando inércias e acomodações nas vidas e nos pensamentos. Sua força vem do grupo, não de um agrupamento com subjetividades capitalísticas, mas do que compartilha tarefas e alimenta, também, afetos. Toma força e energia criativa num debate provocador, mas também é implicada com dispositivos que lhe arrancam o corpo do lugar e lhe transportam para outros espaços e territórios.

O sol é sua energia, de onde emana sua potência afetiva-criativa, movimentos dionisíacos também potencializam sua mente a produzir uma interrogação em momentos de acomodação frente ao instituído.

É incitada pela luta política, provoca outros à indignação contra ações e pensamentos fascistas golpistas, machistas, homofóbicos. O ético-estético-político compõe sua vida o eixo da estética da existência. Num debate com predominância no senso comum, esse eixo vem com força, lançando mão de sua mente dispersa e provocativa.

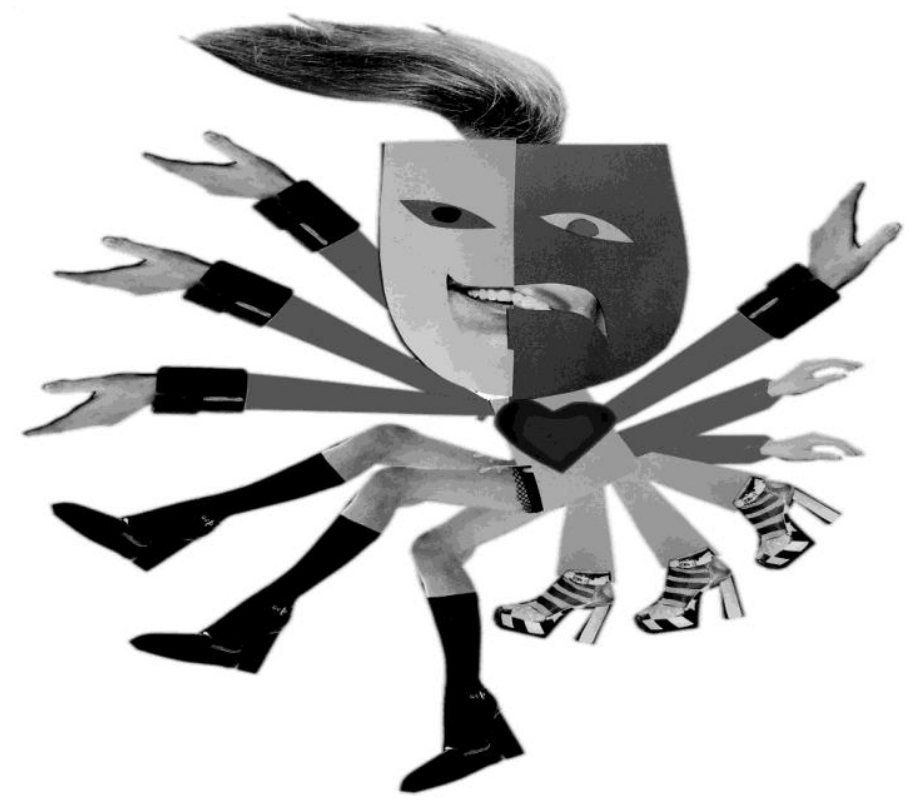

AUTORA: Valeska Fortes de Oliveira 
Na sequência, apresenta-se: Flora e a luta contra os vilões da educação!

Flora sempre gostou de atividades que proporcionassem um certo grau de dificuldade, algo diferente da rotina, um obstáculo. Sempre teve vontade de evoluir e de superar suas limitações para, assim, poder mudar o mundo.

Sua caminhada heroica inicia quando ela, por uma força maior que sua própria vontade, é predestinada à área da educação, a fim de modificar sua estrutura cômoda. Desde sua chegada, sempre teve vontade de ser diferente dentro desse ambiente em que o fácil e o habitual é o comodismo. Nunca se conformou com os vilões que habitam esse meio em que vivemos e fazem as pessoas verem somente o que eles querem, sem nenhum pensamento crítico.

A super-heroína Flora entra em ação quando a ignorância toma conta do pensamento das pessoas, frente aos muitos problemas do mundo, fazendo com que eles tenham um olhar crítico perante os acontecimentos. Ela defende o mundo para que esses vilões, que estão em toda parte, não contagiem mais pessoas com seus raios de aceitação, sendo assim, cria um bloqueio mágico contra isso. Também luta para revidar os efeitos causados pelos ataques dos seus arqui-inimigos, espalhando pelo ar uma substância boa que sai da sua capa de flores e torna os indivíduos mais críticos e pensantes. Ela guerrilha para fazer os indivíduos olharem diferenciadamente para os conceitos criados pelo senso comum e ressignificá-los.

Para realizar tudo isso, ela utiliza como instrumentos uma espada para lutar contra esses vilões e derrotá-los, evitando que esse mal contagie mais pessoas. Além de lutar e defender os indivíduos, ela também utiliza uma defesa para si, um escudo que a protege desses raios de acomodação para que não a afetem.

Como todos, essa heroína também tem seu ponto fraco, ela tem um lado ainda muito humano e, assim, se abala muito facilmente com os problemas do mundo, se entristece e se preocupa muito com as pessoas ao seu redor e esquece, muitas vezes, de cuidar de si mesma e de seus poderes.

Essa atuação heroica ocorre num campo de batalha chamado educação brasileira, na qual existem poucos guerreiros que lutam para mudá-la e torná-la melhor e, infelizmente, a grande maioria, são todos vilões que espalham acomodação pelo mundo! 


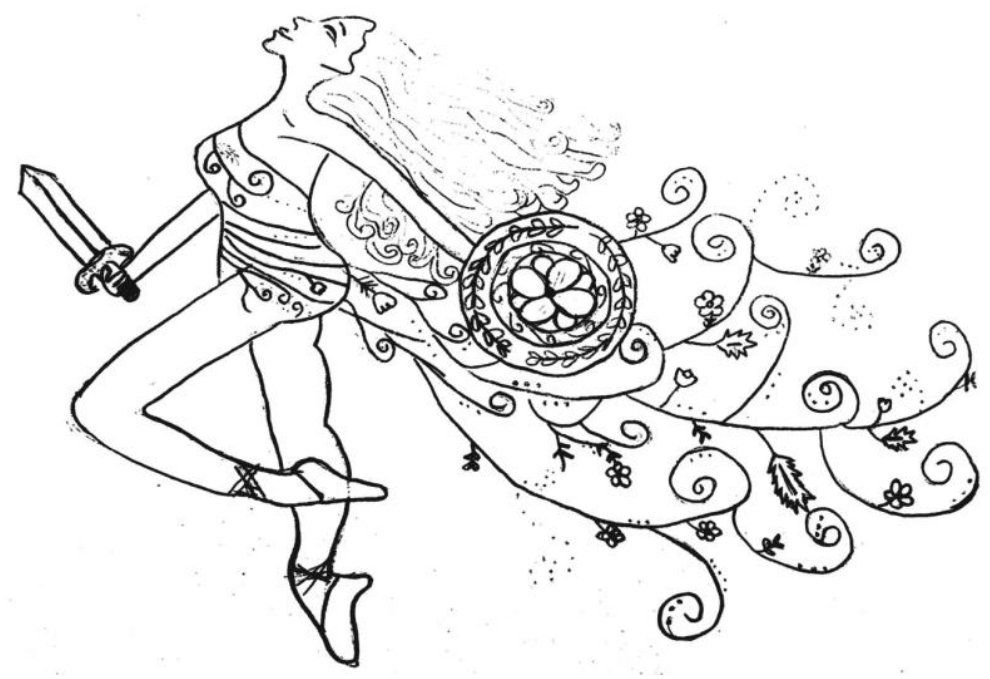

AUTORA: Samara Facco

Pela análise dos textos poéticos criados, pode-se perceber a imensidão de subjetividades que o imaginário de cada um comporta, diferenciando-se, principalmente, por meio da experiência subjetiva vivenciada com a educação, como compõem os textos acima citados. As diferenças, além de serem pelo tempo de atuação no contexto referenciado, mostram também o cansaço com o descaso público pela educação de qualidade e, também, a acomodação pelos próprios construtores dela: os professores.

Apesar das diferenças encontradas, percebe-se algo em comum nas criações grafopoéticas. Por isso, seria importante que essas criações estimulassem os profissionais da educação a encorajarem-se para a criação de um processo de ensino e aprendizagem baseados nos principais interessados, os alunos; e não em práticas curriculares baseadas em reproduções de estereótipos e formas de ser e estar reguladas pelo capital mercantil. É preciso lutar contra o comodismo, extremismo, homofobia, desigualdade, estereótipo instituído na sociedade atual e por uma educação com mais espaço para o imaginário e suas criações, afinal o ser humano se encontra em constantes transformações, não é mesmo? E por que, então, a educação deve permanecer inalterada sem acompanhar essas mudanças?

\section{CONSIDERAÇÕES FINAIS}

Assim, a partir desta experiência, foi possível pensar as questões postas na formação pelo viés do imaginário, em que as significações imaginárias dos acadêmicos e professores acerca da universidade e de seu papel na sociedade puderam ser 
percebidas e pensadas. As perguntas e respostas não são explicitadas, nem as definições são dadas na linguagem, elas acontecem no próprio agir das coletividades. As significações imaginárias formam um magma, de onde se pode extrair e/ou construir inúmeras formas, maneiras de ser e fazer de cada sociedade considerada, em que há uma unidade da instituição total da sociedade: observando-a mais de perto, descobre-se que essa unidade é, em última instância, a unidade e coesão interna do tecido imensamente complexo de significações que impregnam, orientam e dirigem toda a vida daquela sociedade e todos os indivíduos concretos que, corporalmente, a constituem. "Esse tecido é o que eu chamo o magma das significações imaginárias sociais trazidas pela instituição da sociedade considerada, que nela se encarnam e, por assim dizer, a animam" (CASTORIADIS, 1982, p. 239).

Neste sentido, este magma diria que se trata não de algo palpável, mas de algo que está aí, como o próprio autor fala, um tecido invisível, que define e constitui como tal cada sociedade. Os indivíduos estão imersos neste magma de significações e agem conforme ele. Assim, os próprios heróis universitários são frutos deste magma de significações imaginárias, tornando cada um ao mesmo tempo produto e produtor do espaço universitário ao qual pertencem. Acessar estas significações permite compreender um pouco mais o universo universitário, seus dilemas, suas dúvidas, suas conquistas, suas falhas, seus ganhos, seus encantos e desencantos.

Recebido em: 09-07-2018 Aceito em: 09-07-2018

\section{REFERÊNCIAS}

CASTORIADIS, Cornelius. A instituição imaginária da sociedade. Rio de Janeiro: Paz e Terra, 1982.

Sujeito e Verdade no mundo Social Histórico. Rio de Janeiro: Civilização Brasileira, 2007.

CASSIRER, Ernst. Ensaio sobre o homem: introdução a uma filosofia da cultura humana. São Paulo: Martins Fontes, 1994.

FERREIRA, Nilda Teves; EIZIRIK, Marisa Faermann. Educação e Imaginário social: revendo a escola. In: Em aberto. Brasília, n. 61, p. 5-14. jan./mar.,1994.

MASTROBERTI, Paula, COSTA, Luciano Bendin. Super Heroí Universitário. Dicionário Raciocinado das Licenciaturas. Porto Alegre, 2016. 
MORIN, Edgar. Introdução ao pensamento complexo. Lisboa: Instituto Piaget, 1991.

PERES, L.M.V.; EGGERT, E.; KUREK, D.L. (orgs.). 2009. Essas coisas do imaginário: diferentes abordagens sobre narrativas (auto) formadoras. São Leopoldo/Brasília, Oikos/Liber Livro, 198 p.

POSTIC, Marcel. O imaginário na relação pedagógica. Rio de Janeiro: Jorge Zahar, 1993.

PUJOL, M.S.; SEVERO, B. de A.; PERANZONI, V.C. Imaginário e Educação: pensando a formação de professores. VIII Mostra Acadêmica da Fames. 04-05 de novembro de 2015 .

SHOLL, Léa. Desejos sociais "versus" práticas educacionais: uma tensão no imaginário social. In: TEVES, Nilda (org.) Imaginário social e educação. Rio de Janeiro: Gryphus: Faculdade de Educação da UFRJ, 1992. 